\title{
Determinants of Capital Adequacy Ratio for Pension Funds: A Case Study in Indonesia
}

\author{
Sunaryo Sunaryo ${ }^{1}$, Alvia Santoni ${ }^{2}$, Endri Endri ${ }^{3} \&$ Muhammad Nusjirwan Harahap $^{4}$ \\ ${ }^{1}$ Economic and Business Faculty, Universitas Islam As-syafi'iyah, Jakarta, Indonesia \\ ${ }^{2}$ STIE Sakti Alam, Kerinci, Jambi, Indonesia \\ ${ }^{3}$ Universitas Mercu Buana, Jakarta, Indonesia \\ ${ }^{4}$ STIE Keuangan, Perbankan dan Pembangunan, Padang, Indonesia \\ Correspondence: Endri Endri, Lecturer, Universitas Mercu Buana, Jakarta, Indonesia.
}

Received: August 14, 2019

doi:10.5430/ijfr.v11n4p203

\section{Abstract}

The study aims to identify factors that influence adequacy ratio of fund (RKD) of the Defined Benefit Pension Plan (PPMP) Pension Fund for 2009-2018 period such as Return on Asset (ROA), Cash Conversion Rate (CCR), Central Board Revenue (CBR), Operating Expense Ratio (OER), Investment Expense Ratio (IER), and investment. The data analysis was common effect panel data regression method and the samples were twenty pension funds. The results showed that ROA, CCR, and investment have a significant and positive influence towards RKD, CBR and OER have a significant and negative influence towards RKD. IER did not have significant influence towards RKD.

Keywords: adequacy ratio of funds, pension fund, common effect model

\section{Introduction}

Every worker dreams of having a stable income both while working and after retirement. Business institution should pay attention to this aspect because income is closely associated to working motivation. Type of welfare a worker earns after retirement is called pension or retirement fund. Yusof \& Sabri (2017) stated that need for pension fund is determined by several factors including economic, socio-economic and non-economic (psychological and demographical aspects, such as age, level of education, gender and race). Study of Nzioka \& Hazel (2013) described organizational policy, resource, communication, and public policy on pension funds in Sacco Industry in Kenya. Chatterjee (2010) in his study mentioned that number of private and public employees participating in retirement saving is increasing along with age, income, and level of education.

To develop retirement program for their workers, companies (employers) can establish their own pension fund called Employer Pension Fund (DPPK) that consists of two options, namely Defined Benefit Plan (PPMP) or Defined Contribution Plan (PPIP) or register their workers to Financial Institution Pension Fund (DPLK). The 1992 Decree number 11 on Pension Funds stated that Pension Fund is a legal entity authorized to manage and run program that provides retirement benefit. As the entity responsible for managing customer's fund, Pension Fund with PPMP must maintain its adequacy ratio of funds (RKD) to the minimum of $100 \%$. RKD represents number of assets Pension Fund must fulfill its responsibility to its customers, in the form of retirement fund, at present and in the future. Table 1 showed the adequacy ratio of fund of Pension Funds with Defined Benefit Plan obtained from the Financial Services Authority.

Table 1. Adequacy Ratio of Fund (RKD) of PPMP in Indonesia between 2009 and 2018

\begin{tabular}{lllllllllll}
\hline \multicolumn{1}{c}{ Year } & & & & & \\
\hline & $\mathbf{2 0 0 9}$ & $\mathbf{2 0 1 0}$ & $\mathbf{2 0 1 1}$ & $\mathbf{2 0 1 2}$ & $\mathbf{2 0 1 3}$ & $\mathbf{2 0 1 4}$ & $\mathbf{2 0 1 5}$ & $\mathbf{2 0 1 6}$ & $\mathbf{2 0 1 7}$ & $\mathbf{2 0 1 8}$ \\
\hline RKD (\%) & 102.59 & 107.80 & 104.31 & 106.84 & 89.55 & 102.17 & 98.16 & 100.46 & 104.24 & 99.59 \\
\hline
\end{tabular}

Source: Financial Services Authority 
Table 1 indicated that within the last ten years RKD is fluctuating sharply, and in 2013, 2015 and 2018 the percentages of RKD are lower than $100 \%$. RKD refers to ratio between assets and actuarial obligations. Antolin \& Stewart (2009), explained that asset is determined by initial fund, fees, staff contribution, development proceeds and Past Service Liability, while actuarial obligations are determined by increase of salary, retirement benefit, and actuarial assumptions. Zamri \& Eliza (2015), also stated that Pension Fund's asset depends upon development proceeds or return on investment (ROI). ROI is the major revenue of Pension Fund obtained from investment. Sources of the investment are contributions from both Pension Fund's customers and founders. Table 2 showed the Pension Fund's investment from 2009 to 2018.

Table 2. Investment of PPMP in Indonesia between 2009 and 2018

\begin{tabular}{|c|c|c|c|c|c|c|c|c|c|c|c|}
\hline & & \multicolumn{10}{|l|}{ Year } \\
\hline & & 2009 & 2010 & 2011 & 2012 & 2013 & 2014 & 2015 & 2016 & 2017 & 2018 \\
\hline $\begin{array}{l}\text { Investment } \\
\text { (Trillions } \\
\text { Rupiah) }\end{array}$ & of & 84.13 & 96.83 & 102.56 & 112.82 & 112.64 & 127.79 & 130.01 & 139.87 & 149.605 & 147.445 \\
\hline
\end{tabular}

Source: Financial Services Authority

Based on Table 2, the Pension Fund keeps increasing their investment in the last ten years. The investment results in ROI (Return on Investment) shown on Table 3.

Table 3. ROI of PPMP in Indonesia between 2009 and 2018

\begin{tabular}{lllllllllll}
\hline & Year & & & & & & & & \\
& $\mathbf{2 0 0 9}$ & $\mathbf{2 0 1 0}$ & $\mathbf{2 0 1 1}$ & $\mathbf{2 0 1 2}$ & $\mathbf{2 0 1 3}$ & $\mathbf{2 0 1 4}$ & $\mathbf{2 0 1 5}$ & $\mathbf{2 0 1 6}$ & $\mathbf{2 0 1 7}$ & $\mathbf{2 0 1 8}$ \\
\hline ROI $(\%)$ & 21.83 & 16.10 & 7.62 & 12.11 & 3.59 & 7.51 & 9.5 & 7.8 & 7.79 & 8.28 \\
\hline
\end{tabular}

Source: Financial Services Authority

Table 3 showed that ROI between 2009 and 2013 plummeted, but it increases from 2014 to 2018. ROI fluctuation is not directly proportional to the increase of investment fund shown in Table 2, which means the percentages of ROI are plunging too. Discussing relationship between the Pension Fund ROI and RKD, ROI fluctuation in the last ten years is in line with the RKD fluctuation, but development of the investment fund is not directly proportional to RKD. The Pension Fund allocated the investment fund (Table 2) into portfolio as shown in Table 4.

Table 4. Pension fund investment portfolio between 2009 and $2018(\%)$

\begin{tabular}{llllllllllc}
\hline Investment & Year & \multicolumn{1013}{c}{} & $\mathbf{2 0 0 9}$ & $\mathbf{2 0 1 0}$ & $\mathbf{2 0 1 1}$ & $\mathbf{2 0 1 2}$ & $\mathbf{2 0 1 3}$ & $\mathbf{2 0 1 4}$ & $\mathbf{2 0 1 5}$ & $\mathbf{2 0 1 6}$ & $\mathbf{2 0 1 7}$ & $\mathbf{2 0 1 8}$ \\
\hline Stock Market & 71.38 & 70.86 & 68.66 & 67.60 & 67.69 & 61.08 & 48.55 & 46.34 & 48.84 & 47.71 \\
\hline Money Market & 21.92 & 22.89 & 25.33 & 26.27 & 23.87 & 30.24 & 39.48 & 40.25 & 37.37 & 39.51 \\
\hline Land and Building & 3.22 & 3.13 & 3.08 & 3.08 & 4.79 & 5.08 & 7.42 & 8.51 & 8.36 & 8.05 \\
\hline Real Sector & 3.48 & 3.12 & 2.93 & 3.05 & 3.65 & 3.60 & 4.54 & 4.90 & 5.44 & 4.73 \\
\hline Total & 100.00 & 100.00 & 100.00 & 100.00 & 100.00 & 100.00 & 100.00 & 100.00 & 100.00 & 100.00 \\
\hline
\end{tabular}

Source: Financial Services Authority

Table 4 indicated that in the last ten years the Pension Fund make the most investment on stock market, followed by money market, and building, and the real sector. The investment results in ROI in the form of: (1) interest/ profit sharing, (2) dividends, (3) lease, (4) investment release/ acquisition gain (loss), and (5) income from other types of 
investment. The key to increase RKD is to increase profitability or return on assets (ROA) which includes results of investment Pension Fund make. Besides profitability, other factors that affect RKD are liquidity, operational cost efficiency, investment cost efficiency, and cash flow from contributions and payments of retirement benefit, and growth of funds for investment.

Pension Funds which have relatively few retirees and relatively higher monthly contributions have yet to encounter any issue on liquidity. At the opposite, Pension Funds with a relatively large number of retirees and far higher pension payments than the total contributions received can pose a risk of lack of liquid funds (Bikker et al. 2010). Therefore, to overcome liquidity risk, Pension Funds should reduce percentage of investment funds they put as liquidity; however, this move may decrease profitability. High profitability is performance in which reducing costs becomes an emphasis, and thus, an important method to achieve efficient operations is to control costs effectively (Endri, 2019). Cash flow contributions and pension benefits are measured using fund design fund, a comparison between contributions and pension benefits; design fund can affect the return on investment (Chybalski, 2016).

Previous research on pension funds focused on the size, governance, and design of pension plans and outsourcing decisions related to cost efficiency, for example study of Bikker \& Dreu (2009). Antolin et al. (2011) showed that market interest rates are associated with pension fund balances. Study of Davis \& Haan (2012) explained small companies were unprofitable and contributed less to their pension funds than large and profitable companies. Simbabrashe \& Lilian (2014) conducted a study discussing relationship between asset size and profitability. Cremers et al. (2016) discussed total assets and profitability associated with funded (Pension Fund funding capabilities). Thomas et al. (2013) conducted a study on association between stock market volatility and Pension Fund assets. Türegün \& Kaya (2014) evaluated performance of Pension Funds. Very few studies discussing relationship between liquidity, operating and investment costs, cash flow and investment funds with RKD of Pension Funds. Therefore, this study aims to examine the relationship between the factors and RKD.

\section{Literature Review}

\subsection{Adequacy Ratio of Funds (RKD)}

RKD is a financial ratio that shows financial ability or quality of Pension Fund to provide services or pay pension benefits of both retired participants and participants who are still working. Therefore, RKD is a pivotal indicator since the purpose of Pension Fund is to pay the right amount of pension benefit on time and to the right participants.

The Decree of the Minister of Finance number 510/KMK.06/2002 issued on December 4, 2002 on Funding and Solvency of Employer Pension Funds stated that adequacy ratio of funds (RKD) is obtained from dividing Net Assets by Actuarial Obligations. The formula to obtain RKD is as follows:

$$
\mathrm{RKD}=\frac{\text { Net Assets }}{\text { Actuarial Obligation }}=\%
$$

Description:

Net Asset

$=$ Asset $-($ The Decree of the Minister of Finance number 510/KMK.06/2002 issued on December 4, 2002 on Funding and Solvency of Employer Pension Funds Article 6 Paragraph 2).

Actuarial = (1) Pension Fund Obligation obtained based on the assumption Pension Fund run its Obligation business until they have met all obligations to their Customers and other Entitled Parties,

(2) Actuarial Obligation refers to present value of retirement benefit Pension Funds should pay to retired and working customers,

(3) Actuarial Obligation based on actuarial calculation.

Paklina (2017) stated that Pension Fund assets are affected by and obtained from: (1) initial fund, (2) fee, (3) contribution of employee, (4) development proceeds and (5) past service liabilities. Actuarial Obligation refers to Present Value of Total Pension Benefit and is calculated by an actuarial as Past Service Liability.

Amount of Present Value of Total Retirement Benefit or Past Service Liability is determined by increase of salary, retirement benefit and actuarial assumptions. The actuarial assumptions are (Paklina, 2017).):

- Structure of participant's age in general,

- Participant's death due to illness,

- Participant's death due to accident, 
- $\quad$ Birth rate

- Promotion,

- Turnover of employee,

- New participants,

- Retired participants/widow/widower/orphan,

- Structure of participant's salary,

- Change of salary due to promotion, periodical change or inflation,

- Market interest rate,

- Inflation rate.

Orlando \& Politano (2010) stated that the funding ratio at time t, denoted by FR (t), is defined as the ratio of the assets to the liabilities at that time, that is, FR $(\mathrm{t})=\mathrm{A}(\mathrm{t}) / \mathrm{L}(\mathrm{t})$. Morris et al. (2018) also described that the funded ratio is defined as the market value of a fund's assets over the value of its liabilities. Based on those experts, it can be concluded that adequacy ratio of fund is basically a comparison or ratio between assets and actuarial obligations.

Alaudina et al. (2017) argue that indicators of financial sufficiency are Region, Strata (Urban and Rural), Marital status (Married, Single Female and Single Male), Ethnicity (Indonesian, Chinese, Indian, other), Educational level, Occupational group, Employment type, Subjective life expectancy (live $\leq 34,35 \leq$ live $\leq 39,40 \leq$ live $\leq 44,45 \leq$ live $\leq 49,50 \leq$ live $\leq 54)$, and Household income (9.6k - 15k, 15k-25k, 25k - 40k, 40k - 60k, 60k and above). Using Pension Fund with Defined Benefit Pension Plan as the context, relevant variables affecting sufficiency of retirement plan are marital status, level of education, employment type, and average annual income. On the other hand, Li et al. (2014) argued that some factors that determine sufficiency of retirement plan are sufficient income, long-term planning, plan to retire at the age of 65 years old or above, investment (assets), level of education, good health, marital status and occupation (profession).

\subsection{Profitability}

Type of analysis used to measure success rate of Pension Funds in making investment is profitability ratio. Endri et al. (2020) and Brigham \& Houston (2011) argued that profitability is the result of series policies and decisions made by companies in terms of showing a combination of effects of liquidity, asset management, and debt on operating results. Profitability ratios include profit margin on sales, basic ability to generate profits, Return on Investment (ROI) and Return on Equity (Endri \& Fathony, 2020). Endri (2018) argued that profitability is part of performance measure that describes how effective management is based on return on sales and investment.

Nuriyah et al. (2013) classified profitability ratio into two, namely profitability related to sales and one related to investment. Together, both types demonstrate company's efficiency. Ang et al. (2014) stated that performance appraisal is a means for management to find out the extent to which company's goals have been achieved. Using the financial perspective, commonly used indicator to measure efficiency is Return on Investment (ROI) as ROI is a single comprehensive indicator that can explain the trade-offs between income, costs, and investment. Pension Fund profitability is measured using the following formula:

$$
\text { Return on Assets }(\mathrm{ROA})=\frac{\text { Income before Tax }}{\text { Average Value of Assets }}=\%
$$

\subsection{Liquidity}

Broeders (2010) defined liquidity as issues related to ability of a company to meet its financial obligation. Driessen \& De Jong (2012) noted that liquidity is related to ability of company to meet its due obligations. As an addition, Zamri \& Eliza (2015) stated that liquidity refers to ability of company to meet its short-term obligation (within one year). Liquidity is ability to transform assets into cash or ability to generate cash. It is related to normal operation cycle of Pension Funds which includes the investment cycle at stock market, money market, and other types of investment based on cash outflow perspective, and then cash inflow perspective in the form of disbursement of investment fund and result on investment for liquidity. Liquidity is one of the factors that determines success or failure of Pension Fund. In Pension Fund, the indicator of liquidity ratio is Cash Coverage Ratio (CCR) (Endri et al. 2019) that can be obtained using the following ratio: 


$$
\text { Cash Coverage Ratio }=\frac{\text { Cash } / \text { Cash Equivalent }}{\text { Current Liabilities }}=\mathrm{x} \text { atau } \%
$$

Description:

$$
\begin{array}{ll}
\text { Cash } & =\text { Cash, } \\
\text { Cash Equivalent } & =\text { Demand Deposits, Certificate of Deposit, SBI, } \\
\text { Current Liabilities } & =\text { Operational costs plus ready-to-pay pension for minimum } 2 \text { months. }
\end{array}
$$

CCR will provide certainty and security for retirees. Prior to making investment, they should first spend some cash for pension for at least two months.

\subsection{Cashflow}

Cashflow reflects ability of contribution Pension Funds obtain to pay for retirement benefit. Cash flow of contribution and retirement benefit is measured using CBR = Contribution Benefit Ratio, or comparison between contribution and retirement benefit (Andonov et al. 2017). The formula for CBR is as follows:

$$
\mathrm{CBR}=\text { Contribution Benefit Ratio }=\frac{\text { Contribution }}{\text { Retirement Benefit }}=\%
$$

In the context of Pension Fund, the ratio is emphasized from cash flow that illustrates ability of Pension Fund to pay retirement benefits to customers. Source of this retirement benefit is Pension Fund customer's contribution. Contribution is a monthly deposit of funds from participants/ customers and employers, and then Pension Fund uses it for both investment and payment of retirement benefits. The higher contributions to benefit ratio is, the higher the ability of contributions to cover payments, and the more opportunity for Pension Funds to make investment.

There are two reasons why contribution benefit ratio is declining; the first is an increase in number of retired participants increasing amount of retirement benefit Pension Funds should pay, and the second is fewer number of new participants resulting in less amount of contributions and higher amount of retirement benefit.

\subsection{Operating Expenses and Investment Expenses}

Andonov et al. (2017) stated that an indicator to measure efficiency of operation activity is management expenses risk, which is to measure how each type of cost is managed.

Bikker \& Dreu (2009) explained the concept of "operating costs of pension funds. The operating costs of pension funds consist of administrative costs and investment costs. Administrative costs relate to all operational tasks excluding asset management, such as record keeping, communication with participants, policy development and compliance with regulatory and supervisory requirements. These costs include salaries, rents and fees charged by third parties such as actuaries, accountants and lawyers. Investment costs arise from investment analysis, risk management and trading, and include salaries of analysts and portfolio managers, brokerage fees and charges for the use of electronic trading facilities."

In the context of Pension Funds, two indicators used to determine cost efficiency ratio are Investment Expenses Ratio and Operational Expenses Ratio, and their formulas are as follows:

$$
\begin{aligned}
& \text { 1) Investment Expenses Ratio }=\frac{\text { Investment Cost }}{\text { Investment Return }}=\% \\
& \text { 2) Operating Expenses Ratio }=\frac{\text { Beban operasional }}{\text { Investment Return }}=\%
\end{aligned}
$$

Investment Expenses Ratio and Operational Expenses Ratio are two relevant concepts to apply in Pension Funds since Pension Fund is dominated by activities that aim to manage contribution from both participants and employers in order to pay its obligations (payment of retirement benefits).

Investment and Operating Expenses Ratio represents burden Pension Funds should bear compared to income/ investment return. The higher these ratios are, the higher burden Pension Fund has and the less efficient it is.

\subsection{Investment Fund}

Pension Fund is financial institution responsible for management of participant's income once they are retired. Thus, the major goal of Pension Fund is to pay sufficient amount of retirement fund at the right time to the correct retiree 
(Paklina, 2017). To achieve this goal, Pension Fund should invest funding from both participants/ customers and employers into types of investment that has high ROI and low risk. The Regulations of Financial Services Authority number 3/POJK.05/2015 issued on March 31, 2015 Pension Fund Investment explains types of investment Pension Fund can make. Types of investment Pension Fund is allowed to make are as follows:
a. Government Securities,
b. Bank Savings,
c. Time Deposit at Banks,
d. On-call Deposit at Banks,
e. Certificate of Deposit at Banks,
f. Bank of Indonesia Certificate,
g. Shares listed in Indonesia Stock Exchange,
h. Obligation listed in Indonesia Stock Exchange,
i. Sharia Compliant Bonds listed in Indonesia Stock Exchange,
j. Mutual Fund Participation Unit from:
1. Money Market Mutual Funds, Fixed Income Mutual Funds, Mixed Mutual Funds, and Equity Funds,
2. Protected Mutual Funds, Mutual Funds with Guarantees and Index Mutual Funds,
3. Mutual Funds in the form of Limited Participation Collective Investment Contracts,
4. Mutual Funds whose Participation Units are Traded on the Stock Exchange.
k. Asset Backed Securities from the Asset Backed Securities Collective Investment Contract,
1. Participation Unit for Real Estate Investment Trust in the form of Collective Investment Contract,
m. Stock Option Contracts listed in Indonesia Stock Exchange,
n. Direct placement in shares,
o. Land in Indonesia, and/or
p. Building in Indonesia.

Investment fund allocation above is part of allocating Pension Fund's assets to obtain return. Stoughton \& Zechner (2011) defined investment as making long-term investment for one or more assets an individual/ an entity owns in order to gain profit in the future. Ang et al. (2014) argue that investment is commitment to invest certain amount of fund in the present in order to gain some profits in the future. In other words, investment is commitment to make sacrifice and spent less at present in order to be able to spend more in the future. On the other hand, Dyck \& Pomorski (2011) stated that asset management and investment are indicators of operating efficiency shown in investment decision company makes and how company uses its resources.

Pension Fund investment from members of IOPS (International Organization of Pension Supervisors) according to Gorter \& Jacob (2013) at least, such matters as the investment risk measurement methods, the risk-management processes implemented and the strategic asset allocation with respect to the nature and duration of pension liabilities.

Li et al. (2014) stated that factors that determine whether retirement benefit is enough or not are asset or investment in the form of Home, Business equity, Other real estate, Checking or savings account, Savings bonds, Stocks, bonds or mutual funds, and Personal loans to others.

\section{Relationship Between Variables}

\subsection{Profitability Towards RKD (Adequacy Ratio of Fund)}

Endri (2019) stated that profitability is outcome of a series of policy and decision-making companies make showing combining effect of liquidity, asset management, and debt due to operating activities. Profitability ratio includes profit margin on income, the basic ability to generate profits, the rate of return on total assets/ investments (Return on Investment/ ROI). The higher profit Pension Fund generates, the more assets and the higher RKD the Pension Fund has. The first hypothesis in this study is as follows:

H1: There is a positive relationship between profitability and RKD. 


\subsection{Liquidity Towards (Adequacy Ratio of Fund)}

Driessen \& De Jong (2012) defined liquidity as issues related to company's ability to meet its financial obligations. Liquidity is an issue Pension Fund encountered in relation to retirement benefit and operating cost payments. Paklina (2017) argue that in order to overcome liquidity issue, resulting from increase of retirement benefit payment and decreasing contributions, Pension Fund should allocate some parts of its investment portfolio into short-term investments. Franzoni et al. (2012) noted that return (interest rate) of short-term investment is generally lower. Therefore, when Pension Fund allocated too much money on short-term investment, its probability will be decreasing. However, when it allocated to little on short-term investment, it will pose a high liquidity risk which may result in complaints from customers (retirees) and disruption of operating activities. Based on the description, it can be concluded that excessively high liquidity decreases Pension Fund's profitability, assets, and eventually its RKD. Hence, the second hypothesis is as follows:

H2: There is a negative relationship between liquidity and RKD.

\subsection{Cashflow Towards RKD (Adequacy Ratio of Fund)}

Cashflow illustrates ability of both customer's and employer's contribution to cover retirement benefit payments. Cashflow of the contribution and retirement benefit is measured using fund design, comparison between contributions and retirement benefit ( $\mathrm{Ai}$ et al. 2015). Ratio of Contribution to Retirement Benefit is a ratio used to measure ability of the cashflow of contribution and retirement benefits. The contribution refers to assets Pension Fund has spent for investment and payment of retirement benefit. Higher contribution to retirement benefit ratio means that Pension Fund allocates lower percentage of the contribution for payment of retirement benefits, and higher percentage of the fund for investment. This condition will increase both profitability due to increase of investment return and RKD because of increase of assets. This is in accordance to Cremers et al. (2016) that the funding ratio or adequacy ratio of funds (RKD) is the result of changes in the actual assets in investment portfolio and contribution of investment returns. Ai et al. (2015) conducted a study investigating Pension Fund found out that fund design (the ratio between contributions and retirement benefits) has positive influence towards investment return. $\mathrm{Li}$ et al. (2014) revealed that that sufficient income has positive influence towards financial adequacy of Pension Fund. The third hypothesis is as follows:

H3: There is a positive relationship between cashflow and RKD.

\subsection{Operating Expenses Towards RKD (Adequacy Ratio of Fund)}

Jackwerth \& Slavutskaya (2016) stated that a ratio used to measure operating efficiency is cost management ratio, a ratio that measures each type of expense to control. Pension Fund spends its assets for operating activities which include salary (employees, Board of Management and Trustees), Office Expenses, Maintenance, Depreciation Expenses, Third Party Service Expenses, and other Operating Expenses. Pension Fund will spend higher amount on these expenses when it is unable to run its activities in an efficient manner. Inefficient Pension Fund has decreasing RKD. The fourth hypothesis is as follows:

H4: There is a negative relationship between operating expenses and RKD.

\subsection{Investment Expenses Towards RKD (Adequacy Ratio of Fund)}

According to Bikker \& Dreu (2009), funding ratio or adequacy ratio of fund (RKD) changes because of expenses for administrative affairs including investment expenses. Investment expenses consist of transaction cost, land and building maintenance fee, building depreciation fee, investment manager cost, and other types of investment cost. The less efficient Pension Fund in its investment management cost is, the fewer assets and lower RKD it has. Therefore, the fifth hypothesis is as follows:

H5: There is a negative relationship between investment expenses and RKD.

\subsection{Investment Fund Towards RKD (Adequacy Ratio of Fund)}

Paklina (2017) previously mentioned that RKD is asset to actuarial obligation ratio, in which investment becomes one part of Pension Fund's assets. They further explained that composition of investment should at least be $70 \%$ of total assets and as the result, investment, as part of assets, plays significant role towards development of Pension Fund as well as increases RKD. The more assets are allocated for investment, the higher return of investment Pension Funds will obtain. Growth of investment expenses illustrates growth of investment expenses in the past, which represents profitability in the future. Assets are spent for funding operating activities of companies (Nuriyah et al. 2018). Companies that aim to generate more assets will spend more on operating activities. Bhutta \& Hasan (2013) explained that "Better growing firms increase their profitability. If there is an increase in total assets it means it has high growth 
and it tends to be more profitable. We measure growth as a percentage increase in total assets Thus we expect positive relationship between growth rate and profitability of firm." As an addition, Davis \& Haan (2012) investigating Pension Fund revealed that fund size has a significant and positive influence towards investment return. Li et al. (2014) revealed that asset investment has a positive influence towards adequacy ratio of Pension Fund.

Thus, the sixth hypothesis is as follows:

H6: There is a positive relationship between investment fund and RKD.

\section{Method}

Objective of the study was to test the influence of probability, liquidity, operating expenses, investment expenses, cash flow and investment funds towards RKD of Pension Funds with Defined Benefit Pension Program in Indonesia between 2009 and 2018. Profitability was measured with ROA (return on asset), liquidity was measured with Cash Coverage Ratio, cashflow was measured with contribution to retirement benefit ratio, operating expenses were measured using comparison between operating expenses and investment return, investment expenses were measured using comparison between investment expenses and investment return, and investment fund was measured using growth of investment fund.

The population and samples of the study were the Pension Funds in Indonesia with Defined Benefit Pension Plan (PPMP) listed as Pension Fund in Financial Services Authority between 2009 and 2018. At the end of 2018, 164 Pension Funds with PPMP were listed in Financial Services Authority. The period (2009-2018) was selected as one of the objects of the study because of assumption that global crisis ended in 2008, and as the result, the global economy has returned to normal. The sampling technique was purposive sampling technique and the criteria were as follows: (1) Pension Fund that published its financial report on its website, (2) Pension Fund that is registered as member of Asosiasi Dana Pensiun Indonesia (ADPI), Indonesian Association of Pension Funds, and (3) Pension Fund that is willing to provide its financial report directly. The number of Pension Funds that fit the criteria was 20 Pension Funds.

The data analysis method was common effect panel regression data model. Its formula is as follows:

$$
\mathrm{RKD}_{\mathrm{it}}=\beta_{0}+\beta_{1} \mathrm{ROA}_{\mathrm{it}}+\beta_{2} \mathrm{CCR}_{\mathrm{it}}+\beta_{3} \mathrm{CBR}_{\mathrm{it}}+\beta_{4} \mathrm{OER}_{\mathrm{it}}+\beta_{5} \mathrm{IER}_{\mathrm{it}}+\beta_{6} \mathrm{INVEST}_{\mathrm{it}}+\varepsilon_{\mathrm{it}}
$$

$\mathrm{i}=1,2, \ldots \ldots ., \mathrm{N} ; \mathrm{t}=1,2, \ldots \ldots \mathrm{T}$

Description:

RKD = Adequacy Ratio of Fund; ROA $=$ Return on Assets; CCR $=$ Cash Coverage Ratio; CBR $=$ Contribution Benefit Ratio; OER = Operational Expenses Ratio; IER = Investment Expenses Ratio; INVEST = Investment.

\section{Findings and Discussion}

\subsection{Findings}

Table 5 showed result of panel data regression analysis conducted using the common effect method

Table 5. Result of panel data regression analysis with common effect method

\begin{tabular}{|c|c|c|c|c|}
\hline Variable & Coefficient & Std. Error & t-Statistic & Prob. \\
\hline$\overline{\mathrm{C}}$ & 0.989546 & 0.034917 & 28.33985 & 0.0000 \\
\hline$\overline{\mathrm{ROA}}$ & 0.828666 & 0.272465 & 3.041367 & 0.0028 \\
\hline$\overline{\mathrm{CCR}}$ & 0.001506 & 0.000659 & 2.286042 & 0.0236 \\
\hline$\overline{\mathrm{CBR}}$ & -0.041618 & 0.008668 & -4.801574 & 0.0000 \\
\hline OER & -0.344891 & 0.155165 & -2.222728 & 0.0277 \\
\hline IER & -0.138781 & 0.192106 & -0.722420 & 0.4711 \\
\hline INVEST & 0.290462 & 0.075084 & 3.868510 & 0.0002 \\
\hline R-squared & 0.314943 & & Mean dependent var & 1.493927 \\
\hline Adjusted R-squared & 0.287902 & & S.D. dependent var & 0.817721 \\
\hline S.E. of regression & 0.110700 & & Sum squared resid & 1.862686 \\
\hline F-statistic & 11.64657 & & Durbin-Watson stat & 1.056468 \\
\hline Prob (F-statistic) & 0.000000 & & & \\
\hline
\end{tabular}


Based on Table 5, formula of the panel data regression model is as follows:

$$
\mathrm{RKD}_{\mathrm{it}}=0.9895+0.828 \mathrm{ROA}_{\mathrm{it}}+0.0015 \mathrm{CCR}_{\mathrm{it}}-0.0416 \mathrm{CBR}_{\mathrm{it}}-0.3448 \mathrm{OER}_{\mathrm{it}}-0.1387 \mathrm{IER}_{\mathrm{it}}+0.2904 \mathrm{INVEST}_{\mathrm{it}}
$$

$\mathrm{C}=$ parameter of constant $=0.9895$, where RKD is 0.9895 or $98.95 \%$ with the assumption that ROA, CCR, CBR, OER, IER and INVEST equal to zero.

Table 5 showed that F-Statistic was 11.646 and the probability was 0.0000 or lower than $\alpha=0.05$ that means $\mathrm{H} 0$ can be rejected. It means that ROA, CCR, CBR, OER, IER and INVEST simultaneously can determine RKD of Pension Funds with PPMP in Indonesia significantly with the level of confidence of $95 \%$. Coefficient of determination $\left(\mathrm{R}^{2}\right)$ was 0.3149 or $31.49 \% 31.49 \%$ can be explained using the ROA, CCR, CBR, OER, IER and INVEST (independent variables), while the remaining $68.51 \%$ is explained by other variables outside the model.

Based on the t-test, the independent variables (ROA, CCR, CBR, OER and INVEST) had significant influence towards RKD with the probability scores of 0.0028 (ROA), 0.0236 (CCR), 0.000 (CBR), 0.0277 (OER) dan 0.0002 (INVEST) or lower than $\alpha=0.05$. On the other hand, IER did not have significant influence towards RKD with the probability score of 0.4711 or higher than $\alpha=0.05$.

\subsection{Discussion}

Profitability, measured using ROA, has a positive and significant influence towards RKD ratio. The empirical finding is in accordance to the hypothesis. Finding of this study showed that increase of ROA results in increase of RKD. Pension Fund profitability represents ability of Pension Fund to generate higher income compared to burden from assets it should manage. Increase of ROA will increase assets Pension Funds have and with assumption that actuarial obligation remains the same, increase of ROA will also increase. RKD is obtained from dividing assets with actuarial obligations.

Liquidity, measured using cash coverage ratio (CCR), has a positive and significant influence towards RKD. The empirical finding did not support the hypothesis. The positive analysis results mean that Pension Fund's RKD will increase when there is an increase of liquidity. Excessively high liquidity Pension Funds provide for payments of both retirement benefit and operating activities decreases some amount of money allocated for investment and return of investment, which eventually will cause decline of profitability (ROA) and RKD. Theoretically, liquidity has negative influence towards RKD, but the analysis result showed that liquidity (CCR) had positive influence towards RKD. It means that, as their liquidity kept increasing, the Pension Funds were able to increase their return of investment.

Cash flow, measured using CBR (Contribution Benefit Ratio) has a negative and significant influence towards RKD. This empirical finding did not support the hypothesis. The negative analysis results mean that the Pension Fund's RKD will decrease when their cashflow increases. Cashflow reflects ability of the contribution to cover retirement benefit payments or how much contributions left after the retirement benefit payments have been paid. Therefore, the more money left after the retirement benefits payments, the higher the RKD is. Theoretically, cashflow has a positive influence towards RKD, but findings of the study showed that cashflow (CBR) had a negative influence on RKD. It is in line with Li et al. (2014) that sufficient income from participants had a positive influence on adequacy ratio of Pension Funds. Sufficient income from these participants will encourage an increase in contributions, which will have a positive impact on the financial adequacy of pension funds. In this study CBR is decreasing due to increasing number of retirees and decreasing number of new participants/ customers; these cause decline in amount of funding for investment and reduce investment returns. However, this condition can still increase the profitability of the Pension Funds. It illustrates the ability of the Pension Fund management to invest, as well as increase their assets and RKD.

Operating expenses, measured with Operational Expenses Ratio (OER), has negative and significant influence towards RKD. The empirical finding is in line with the hypothesis. The negative test result means that Pension Fund RKD will increase when their operating expenses are declining. The finding proves that increase of OER results in decrease of RKD. The more efficient the Pension Funds are in managing their operational costs, the more assets and the higher RKD they will have.

Investment expenses, measured with Investment Expenses Ratio (IER), have a negative and significant influence towards RKD. The empirical finding did not support the hypothesis. It indicates that IER volatility does not affect RKD ratio as the Pension Funds allocated only small percentage of their assets for investment in stock market, money market or other types of investment.

Investment funds, measured by investment growth, have a positive and significant influence towards RKD. The empirical finding supports the hypothesis. It proves that increase in investment results in increase in RKD. Investment funds are Pension Fund's assets that will contribute to investment returns. Sources of investment funds 
are contributions from both participants / customers and employers as well as investment returns. The findings of the study illustrate that allocating contributions for investment can result in increase in investment return that has a positive influence towards RKD. The findings are in accordance to Li et al. (2014) that invested assets (Home, Business equity, Other real estate, Checking or savings accounts, Savings bonds, Stocks, bonds or mutual funds, Personal loans to others) have a positive influence towards financial adequacy of Pension Funds.

\section{Conclusion}

This research is important because it involves two things; first, for companies in pension funds it is important to consider the determinants that can affect the fund adequacy ratio (RKD), and second, research related to determinants of RKD is still not the most especially in empirical research in Indonesia. The results revealed that the variable profitability (ROA), liquidity (CCR) and investment funds (INVEST) affect the RKD positively and significantly. Variable cash flows (CBR) and operating costs (OER) affect RKD negatively and significantly. The investment cost variable (IER) has no significant negative effect on the RKD. It is also important to further develop this research by considering other variables that are thought to affect the RKD in terms of actuarial liabilities, namely an increase in pension benefits, an increase in basic salary for the calculation of pension benefits and contributions, changes in actuarial interest assumptions.

\section{References}

Ahmad, Z., \& Nor, E. (2015). Pension Fund Performance in East Asia: A Comparative Study. Eurasian Journal of Economics and Finance, 3(2), 42-61. https://doi.org/10.15604/ejef.2015.03.02.005

Ai, J., Brockett, L. P., \& Jacobson, F, A. (2015). A new defined benefit pension risk measurement methodology. Insurance: Mathematics and Economics, 63, 40-51. https://doi.org/10.1016/j.insmatheco.2015.03.027

Andonov, A., Bauer, R. M. M. J., \& Cremers, M. (2017). Pension Fund Asset Allocation and Liability Discount Rates. Review of Financial Studies, 30(8), 2555-2595. https://doi.org/10.1093/rfs/hhx020

Ang, A., Papanikolaou, D., \& Westerfield, M. (2014). Portfolio choice with illiquid assets. Management Science, 60(11), 2737-2761. https://doi.org/10.1287/mnsc.2014.1986

Antolin, P., \& Stewart, F. (2009), Private Pensions and Policy Responses the Financial and Economic Crisis. OECD Working Paper Series in Insurance and Private Pensions, No. 36. https://doi.org/10.1787/fmt-v2009-art5-en

Antolin, P., Schich, S., \& Yermo, J. (2011). The Economic Impact of Protracted Low Interest Rates on Pension Funds and Insurance Companies. OECD Journal: Financial Market Trends, 2011(1), 1-20. https://doi.org/10.1787/fmt-2011-5kg55qw0m561

Bhutta, N. T., \& Hasan, A. (2013). Impact of Firm Specific Factors on Profitability of Firms in Food Sector. Open Journal of Accounting, 2, 19-25. https://doi.org/10.4236/ojacct.2013.22005

Bikker, J. A., Broeders, D. W. G. A., \& de Dreu, J. (2010). Stock market performance and pension fund investment policy: rebalancing, free float, or market timing?. International Journal of Central Banking, 6, 163-184.

Bikker, J., \& Dreu, J. De. (2009). Operating Costs of Pension Funds: The Impact of Scale, Governance and Plan Design. Journal of Pension Economics and Finance, 8(1), 63-89. https://doi.org/10.1017/S1474747207002995

Brigham, E. F., \& Houston, J. F. (2011). Essentials of Financial Management (7th ed.). The Dryden Press, Orlando.

Broeders, D. (2010). Valuation of contingent pension liabilities and guarantees under sponsor default risk. Journal of Risk and Insurance, 77(4), 911-934. https://doi.org/10.1111/j.1539-6975.2010.01357.x

Chatterjee, S. (2010). Retirement Savings of Private and Public Sector Employees: A Comparative Study. The Journal of Applied Business Researc, 26(6), 95-102. https://doi.org/10.19030/jabr.v26i6.332

Chybalski, F. (2016). The Multidimensional Efficiency of Pension System: Definition and Measurement in Cross-Country Studies. Soc Indic Res, 128, 15-34. https://doi.org/10.1007/s11205-015-1017-3

Cremers, M., Ferreira, M., Matos, P., \& Starks, L. (2016). Indexing and active fund management: international evidence. Journal of Financial Economics, 120, 539-60. https://doi.org/10.1016/j.jfineco.2016.02.008

Davis, E. P., \& De Haan, L. (2012). Pension fund finance and sponsoring companies. Journal of Pension Economics and Finance, 11(3), 439-463. https://doi.org/10.1017/S1474747212000030

Driessen, J., \& De Jong, F. (2012). Liquidity risk premia in corporate bond markets. Quarterly Journal of Finance, 2(2). https://doi.org/10.1142/S2010139212500061 
Dyck, A., \& Pomorski, L. (2011). Is bigger better? Size and performance in pension plan management. Rotman School of Management Working Paper, No. 1690724. https://doi.org/10.2139/ssrn.1690724

Eljelly, A. (2004). Liquidity-Profitability Tradeoff: An empirical Investigation in an Emerging Market. International Journal of Commerce \&Management, 14(2), 48-61. https://doi.org/10.1108/10569210480000179

Endri, E., \& Fathony, M. (2020). Determinants of firm's value: Evidence from financial industry. Management Science Letters, 10(1), 111-120. https://doi.org/10.5267/j.msl.2019.8.011

Endri, E., Sumarno, A., \& Saragi, H. (2020). Analysis of Financial Performance: Evidence from Food and Beverage Companies in Indonesia. International Journal of Advanced Science and Technology, 29(5), 4199-4208.

Endri, E., Mustafa, B., \& Rynandi, O. (2019). Determinants of Debt Policy of Real Estate and Property Companies Listed on the Indonesia Stock Exchange. International Journal of Economics and Financial Issues, 9(2), 96-104. https://doi.org/10.32479/ijefi.7618

Endri. (2019). Determinant of Firm's Value: Evidence of Manufacturing Sectors Listed in Indonesia Shariah Stock Index. International Journal of Recent Technology and Engineering (IJRTE), 8(3), 3995-3999. https://doi.org/10.35940/ijrte.C5258.098319

Franzoni, F., Nowak, E., \& Phalippou, L. (2012). Private equity performance and liquidity risk. Journal of Finance, 67(6), 2341-2373. https://doi.org/10.1111/j.1540-6261.2012.01788.x

Gorter, J., \& Bikker, J. (2013). Investment risk taking by institutional investors, Applied Economics, 45(33), 4629-4640. https://doi.org/10.1080/00036846.2013.795282

Idayuwati, A. R., Noriszura, I., \& Zaidi, I. (2017). Determinants of Retirement Wealth Adequacy: A Case Study in Malaysia. Jurnal Institutions and Economies, 9(1), 81-98.

Jackwerth, J., \& Slavutskaya, A. (2016). The total benefits of alternative assets to pension fund portfolios. Journal of Financial Markets, 31, 25-42. https://doi.org/10.1016/j.finmar.2016.06.002

Morris, S., Shim, I., \& Shin, H. S. (2017). Redemption risk and cash hoarding by asset managers. Journal of Monetary Economics, 89, 71-87. https://doi.org/10.1016/j.jmoneco.2017.03.008

Nuriyah, A., Endri, E., \& Yasid, M. (2018). Micro, Small-Financial Financing and its Implications on the Profitability of Sharia Banks. DeReMa Jurnal Manajemen, 13(2), 175-197. https://doi.org/10.19166/derema.v13i2.1054

Nzioka, K. A., \& Hazel, G. (2013). Factors That Influence the Implementation of Employee Benefits Programs in the Savings and Credit Cooperative Society Industry in Kenya: A Case Study of a Savings and Credit Cooperative Society in Kenya. International Journal of Business and Commerce, 2(11), 16-32.

Orlando, A., \& Politano, M. (2010). Pension funds risk analysis: stochastic solvency in a management perspective. Problems and Perspectives in Management, 8(2), 160-164.

Paklina, N. (2017). The role of supervision related to consumer protection in private pension systems. IOPS Working Papers on Effective Supervision No.27

Stoughton, N., \& Zechner, J. (2011). Intermediated investment management. The Journal of Finance, 66(3), 779-805. https://doi.org/10.1111/j.1540-6261.2011.01656.x

Thomas, A., Spataro, L., \& Mathew, N. (2013). Pension funds and Stock Market Volatility: An Empirical Analysis of OECD Countries. Discussion Papers, del Dipartimento di Economia e Management-Università di Pisa. https://doi.org/10.1016/j.jfs.2014.01.001

Türegün, N., \& Kaya, C. T. (2014). Integrated Reporting for Turkish Small and Medium-Sized Enterprises. International Journal of Economics, Finance and Management, 3(1), 22-27.

Yusof, R., \& Sabri, M. F. (2017). Determinants of Retirement Savings. Malaysian Journal of Consumer and Family Economics, 20(S2), 167-182. 